\title{
A fütéstechnikai termékek marketingsajátosságai, avagy minőségértékelési jellegzetességek a vásárlási döntési folyamatban
}

\author{
Munkácsi Noémi \\ Budapesti Műszaki és Gazdaságtudományi Egyetem
}

\begin{abstract}
A TANULMÁNY CÉLJA
A magas müszaki intenzitású, fogyasztói termékek kategóriájába tartozó fütéstechnikai termékek kiválasztása során a fogyasztók az elkövetkező 15-20 évre vonatkozó, befektetés jellegü döntést hoznak. A kutatás célja feltárni ezen vásárlási döntési folyamat marketingsajátosságait, azonosítva a minőséget meghatározó értékelési tényezőiket, illetve az ahhoz kapcsolt márkákat, amelyeket a fogyasztók a döntési folyamat különböző szintjein észlelnek. További cél egy korábbi - a fütéstechnikai termékek végfelhasználói márkaválasztására irányuló - szakértői megkérdezés eredményének tovább gondolása és a jelen, a minőség szerepére összpontosító kutatás eredményeinek ütköztetése.
\end{abstract}

\section{ALKALMAZOTT MÓDSZERTAN}

A marketingsajátosságok és a minőségi tényezők feltárása céljából egy kétlépcsős primer kutatás került lefolytatásra 2013 decemberében a magyar lakosság körében, fogyasztókkal készített mélyinterjúk és online kérdőives felmérés formájában.

\section{LEGFONTOSABB EREDMÉNYEK}

A primer kutatás eredményei szerint a válaszadók a vásárlási döntési folyamat több szintjén észlelnek a fogyasztói és az ipari piacra vonatkozó, minőségértékelési tényezőket. A fogyasztók a végső döntés meghozatalakor az ár-érték arány tényezőjét és a megbízhatóságot tartják a legfontosabbnak, mely igazolja a korábbi szakértői megkérdezés feltételezését, és mely cáfolja a szervizes szakemberek fogyasztókról alkotott, ezen vonatkozású elképzelését. A válaszadók számos márkát érzékelnek a magyar fútéstechnikai piacon a vásárlási döntési folyamat különböző szintjein (a fütéstechnikai piac heterogén), azonban a márkák közötti differenciálás szintje alacsony.

\section{GYAKORLATI JAVASLATOK}

A fütéstechnikai termékeket gyártó vállalatok értékesítési- és marketing stratégiájának optimalizálása, a kutatás során feltárt minőségértékelési tényezők mentén.

Kulcsszavak: lakossági fütéstechnikai termékek, fogyasztói vásárlási döntés, minőségértékelés 


\section{BEVEZETÉS - A TÉMA AKTUALITÁSA}

A meleg az emberiség egyik alapvető szükséglete, melyet őseink a laktér közepén rakott nyílt tűz használatával állítottak elő és a tetőn vágott nyíláson át vezették el a keletkezett füstöt (Hansen 1999) Az első modern, központi fütési rendszert i.e. I. században a Római Birodalomban építették, melyben a kemencében elégetett égéstermék földalatti vezetékeken keresztül juttatta el a hőt, melyet aztán kéményeken keresztül vezettek el a szabadba (Cowan 1987). A XXI. században a fütéstechnikai rendszerek jelentőségüket tekintve messze túlmutatnak a hőtermelés lehetőségén: lakossági és ipari épületek stratégiai szintü energetikai rendszeréért (fütés, hűtés, szellőztetés, klimatizálás, klímakomfort) és fenntartható energiafelhasználásáért felelösek (Day et al. 2003).

A mai fütéstechnikai piac sokszínűségét és egyben marketing-szempontú kutatási sajátosságát több tényezö is jelzi. Egyrészt a számos piaci szereplő (pl. fogyasztók, szerelők, gyártók, értékesítők, tervezők, szerviz szakemberek, stb.), akik egyéni érdekeknek megfelelően befolyásolják a piac müködését; másrészt a diverzifikált termékválaszték (pl. hagyományos és kondenzációs gázkazán, olaj-, elektromos- és szilárdtüzelésü kazán, stb.) melyből a megfelelő fütéstechnikai termék kiválasztása történik. A fogyasztóknak számos kettősséggel kell szembe nézniük a fütéstechnikai termékek vásárlási folyamata során: pl. magas müszaki intenzitású és drága terméket vásárolnak alapvetö szükséglet (hö, meleg víz) kielégítése céljából. A magas beruházási költség, valamint a termék műszaki teljesítményével kapcsolatos bizonytalanság hatással vannak a vásárlási döntési folyamatra (Rai et al. 2016), a megvásárolt technológiára és márkára. Ezen bonyolult vásárlási döntési folyamat mentén a fogyasztó a termékminőséget „érzékeli és elismeri” (Vágási 2001, 95).

Jelent tanulmányban kétlépcsős fogyasztói megkérdezés során feltárásra kerültek a fogyasztói vásárlási döntési folyamat szakaszai, a minőség érzékelésének szintjei és tényezői, valamint a termékminőségi tényezőkhöz kapcsolt, fogyasztók által észlelt márkák. Míg a 2014-ben, szerzőtársaimmal publikált kutatásunk (Vágási és tsai 2014) a szerelő szakemberek megkérdezésével azonosította a fogyasztók számára fontos minőségértékelési tényezőket, addig jelen fogyasztói megkérdezés eredményeiből levont következtetések lehetőséget biztosítanak a korábbi kutatással való ütköztetésére, illetve a fogyasztói minőségérzékelés pontosabb megismerésére.

\section{A FÜTÉSTECHNIKAI TERMÉKEK MARKETINGSAJÁTOSSÁGAI A FOGYASZTÓI VÁSÁRLÁSI DÖNTÉSHOZATALBAN}

Marketing-termékklasszifikáció tekintetében a háztartási fütéstechnikai termékek olyan lakossági műszaki termékek, melyek alapvető kettősséget hordoznak magukban (Vágási és tsai. 2014). Egyrészt őrzik a tartós fogyasztási cikkek jellegzetességeit, erősen müszaki jellegúek, termékfejlesztésük a fenntarthatóság, az energiatakarékosság, szabványositás feltételeihez szabottak. Kiválasztásuk, tervezésük, szerelésük és karbantartásuk szakemberhez (szerelö, tervező) kötött. Emellett olyan napi használatú háztartási termékek, melyek az alapvetö emberi szükségletet (meleg víz, hőérzet) hivatottak szolgálni. A magas műszaki intenzitás és ipari jelleg, valamint az alapvető szükségletet kielégítő szerepkör kettőssége olyan sajátos marketingtulajdonságokkal ruházza fel a fütéstechnikai terméket, mely különböző kutatási céloknak ad teret a fogyasztói vásárlási döntéshozatalban.

A fütéstechnikai termékek marketingsajátosságait a nemzetközi tudományos szakirodalom több szempontból vizsgálta. ${ }^{1} \mathrm{~A}$ fogyasztói vásárlási döntési folyamatban felmerül az érzelmeken versus racionalitáson alapuló döntéshozatal kettősségének dilemmája. A fogyasztók energiatakarékos lakásfelújítással kapcsolatos döntéseiben nemcsak a racionalitás és a gyakorlatiasság, hanem a szimbolikus fogyasztás, a komfortérzet, a kívánt státus elemei is kiemelkedő szerepet játszanak (Aune 2007). Így a fütéstechnikai termékek gyártóinak nemcsa a konkurens márkákkal kell „versenyezniük”, hanem a dekoratív, esztétikai élményt nyújtó lakáselemek gyártóival (pl. konyhabútor, szaniter, csempe, stb.) is.

A racionális döntéshozatalt igazolja az is, hogy a fogyasztók a fütéstechnikai termékek vásárlását befektetés jellegü döntéshozatalnak tekintik (Kaezing \& Wüstenhagen 2008). Ebben az esetben

\footnotetext{
${ }^{1}$ Mivel jelen cikk a fogyasztói döntéshozatal sajátosságait vizsgálja a minőségértékelési tényezők tükrében, így a bemutatott marketingsajátosságok erre a vonatkozásra összpontosítanak, és nem terjednek ki pl. az ipari piac vonatkozásának vizsgálatára.
} 
akkor döntenek egy termék megvásárlása mellett (különös tekintettel az innovatív, megújuló energiákon alapuló energiatakarékos megoldások esetében), ha a befektetés megtérülése gyors. (Faiers et al. 2007) Wüstenhagen \& Kaezing (2010) szerint a fogyasztók energiatakarékos fütési megoldások vásárlásánál a kezdeti (befektetési) költségeket mérlegelik a müködési költségek függvényében.

A fütéstechnikai termékek további marketingsajátossága a bonyolult és megfontolt vásárlási döntési folyamat (Kaezing \& Wüstenhagen 2008), melyet az elmúlt években számos nemzetközi kutatás vizsgált. Ezen kutatások - többek között - Rogers (2003) innováció diffúziója elméletére alapulnak, és azt vizsgálják, hogy milyen tényezők mentén adaptálják a fogyasztók az egyes innovatív, energiatakarékos épületgépészeti megoldásokat. Ilyen diffúziós elméleten alapuló kutatások készültek különböző fütéstechnikai és egyéb energetikai megoldások ( $\mathrm{pl}$. napelem, napkollektor) esetében. Az 1. sz. táblázat ezen korábbi kutatásokat, illetve az adaptációt meghatározó tényezőként tekinti át.

\section{1. táblázat: Innovatív fütési megoldások adoptációjának befolyásoló tényezői a termékminőség tükrében}

\begin{tabular}{|c|c|c|}
\hline \multirow[t]{6}{*}{ Termékjellemzők } & $\begin{array}{l}\text { Energiaforrás fajtája } \\
\text { és költsége }\end{array}$ & $\begin{array}{l}\text { Fütéstechnikai termékek (Gustavsson, Joelsson 2007) } \\
\text { Központi fütés (Chen et al. 2012) }\end{array}$ \\
\hline & Fütésszabályozás & Távfütés (Wissner 2014) \\
\hline & $\begin{array}{l}\text { Befektetési és üzemel- } \\
\text { tetési költségek }\end{array}$ & $\begin{array}{l}\text { Innovatív fütési megoldások (Mahapatra, Gustavsson } \\
\text { 2010) } \\
\text { Fütéstechnikai rendszerek (Stolyarova et al. 2015) } \\
\text { Fa- és pellet tüzelésű kazánok (Rouvinen, Matero 2013) }\end{array}$ \\
\hline & Megbízhatóság & $\begin{array}{l}\text { Innovatív fütési megoldások (Mahapatra, Gustavsson } \\
\text { 2010; 2008a;b ) }\end{array}$ \\
\hline & Környezeti hatás & $\begin{array}{l}\text { Innovatív fütési megoldások (Mahapatra, Gustavsson } \\
\text { 2010; Stolyarova et al. 2015; Achtnicht 2011; Gustavs- } \\
\text { son, Joelsson 2007) } \\
\text { Központi fütés (Chen et al. 2012) }\end{array}$ \\
\hline & Beltéri levegőminőség & $\begin{array}{l}\text { Innovatív fütési megoldások (Mahapatra, Gustavsson } \\
\text { 2008b) }\end{array}$ \\
\hline \multirow[t]{3}{*}{ Támogatások } & Elérhetőség & $\begin{array}{l}\text { Fütési rendszerek (Mahapatra, Gustavsson 2008a; } \\
\text { Stolyarova et al. 2015) } \\
\text { Energiatakarékos fütés felújítás (Nair, Mahapatra 2011) } \\
\text { Lakossági fütési rendszerek (Michelsen, Madlener 2013) }\end{array}$ \\
\hline & Korlátok & $\begin{array}{l}\text { Napelem (Faiers et al. 2006) } \\
\text { Lakossági fütési rendszerek (Claudy et al. 2011) } \\
\text { Napelemes rendszerek (Strupeit, Palm 2016) }\end{array}$ \\
\hline & $\begin{array}{l}\text { Hozzáférhető } \\
\text { információ }\end{array}$ & $\begin{array}{l}\text { Energiatakarékos fütés felújítás (Nair, Mahapatra 2011) } \\
\text { Innovatív fütési megoldások (Mahapatra, Gustavsson } \\
\text { 2010) }\end{array}$ \\
\hline
\end{tabular}

Forrás: saját szerkesztés 
Megállapítható, hogy bizonyos technológiák sikeres adaptációjában az energia fajtája, költsége, szabályozhatósága és megbízhatósága, valamit az elérhető támogatások játszották a fő szerepet. Ezen korábbi kutatások szerint a fogyasztók a különböző termékjellemzőket értékelő kritériumként észlelték a vásárlási döntési folyamat során. Ezek egyrészt gazdasági tényezők voltak: befektetési költségek (Mahapatra \& Gustavsson 2008a; 2010; Tapaninen et al. 2009a), müködési költségek (Wüstenhagen \& Kaezing 2010), ár-érték arány és garancia (Stolyarova et al. 2015). Másrészt müszaki tényezők: megbízhatóság (Mahapatra, Gustavsson 2008a; 2010) és komforttényezők (Mahapatra, Gustavsson 2008a), harmadrészt pedig kockázati tényezők, melyek a megfizethetőségre (Tapaninen et al. 2009a;b), a szolgáltatás megbízhatóságára (Mahapatra, Gustavsson 2008a), illetve a társadalmi környezet elfogadására (Tapaninen et al. 2009b) irányultak.
A korábbi szakirodalmi kutatásokat figyelembe véve, valamint a fütéstechnikai termékek jellemzőiben fellelhető ipari és fogyasztói piaci jellegzetességek kettősségére alapozva, a 2. sz. táblázat mutatja be a fütéstechnikai termékek vásárlási döntési folyamatát. Feltételezem, hogy a fogyasztói döntéshozatali folyamat olyan ipari döntési sajátosságokkal egészül ki (2. táblázatban vastagon keretezett rész), mint pl.:

- a fütéstechnikai termékekkel szembeni igény leírása (pl. a lakótérnek megfelelö paraméterezés, a fogyasztás szabályozása, stb.)

- a termékkel szembeni elvárt jellemzők meghatározása (pl. energiatakarékosság, teljesítmény)

- a beszerzési források meghatározása illetve az ajánlatkérés (szerelő szakember kiválasztása, ár, kedvezmények, támogatási lehetőségek, szállítási feltételek, készlet, fizetési feltételek, stb.)

\section{2. táblázat A fütéstechnikai termékek feltételezett vásárlási döntési lépései}

\begin{tabular}{|c|c|c|}
\hline $\begin{array}{l}\text { A fogyasztói vásárlási } \\
\text { döntés lépései }\end{array}$ & $\begin{array}{c}\text { A fütéstechnikai termékek } \\
\text { feltételezett vásárlási döntés } \\
\text { lépései }\end{array}$ & $\begin{array}{c}\text { Az ipari beszerzési döntés } \\
\text { lépései }\end{array}$ \\
\hline \multirow[t]{3}{*}{ 1. A probléma felismerése } & 1. A probléma felismerése & 1. A probléma felismerése \\
\hline & 2. Az igény általános leírása & 2. Az igény általános leírása \\
\hline & $\begin{array}{l}\text { 3. A termékjellemzők megha- } \\
\text { tározása }\end{array}$ & $\begin{array}{l}\text { 3. A termékjellemzők meghatá- } \\
\text { rozása (specifikációk) }\end{array}$ \\
\hline \multirow[t]{2}{*}{ 2. Információgyüjtés } & $\begin{array}{l}\text { 4. Aktív termék- és potenciális } \\
\text { beszerzési forrásra vonatkozó } \\
\text { információgyüjtés }\end{array}$ & $\begin{array}{l}\text { 4. A potenciális beszerzési } \\
\text { források (szállítók keresése) }\end{array}$ \\
\hline & 5. Ajánlatkérés & 5. Ajánlatkérés \\
\hline 3. Alternatívák értékelése & 6. Alternatívák értékelése & $\begin{array}{l}\text { 6. Az ajánlatok értékelése és a } \\
\text { szállítók kiválasztása }\end{array}$ \\
\hline 4. Vásárlás & 7. Megrendelés, vásárlás & 7. Megrendelés \\
\hline 5. A vásárlás értékelése & 8. A vásárlás értékelése & 8. A teljesítés értékelése \\
\hline
\end{tabular}

Forrás: Munkácsi - Grőger 2011, Vágási 1998 alapján 
A fogyasztói magatartás szakirodalma szerint a fogyasztók a vásárlási döntési folyamat során a minőséget különböző minőségértékelési tényezők mentén érzékelik. A fütéstechnikai termékek feltételezett minőségértékelési tényezőit a fogyasztói (Garvin 1988) és ipari (Hart 1989) termékek termékminőségi alkotóelemeinek összevetésével határoztam meg, melyet szerzőtársaimmal a 2014-ben megjelent kutatásunkban mutattunk be. (Vágási és tsai. 2014) A tartósság, a megbízhatóság, a stílus és design olyan ismérvek, melyek mind a fogyasztói, mind pedig az ipari piac termékeire jellemzőek, így feltételezésem szerint a fütéstechnikai termékek esetében is jellemző. Továbbá úgy vélem, a fütéstechnikai termékek olyan további ipari minőségértékelési ismérvekkel egészülnek ki, mint pl. műszaki jellemzök, a könnyü használat, stb. Továbbá feltételezem, hogy a fogyasztók a vásárlási döntési folyamat során különböző fütéstechnikai márkákat észlelnek, melyeket az észlelt minőségi tényezőkkel azonosítanak. Fütéstechnikai termékek fogyasztói márkaválasztási preferenciájára vonatkozó, minőségértékelés tekintetében folytatott kutatást a szakirodalomban nem találtam, így az empirikus kutatásom során kerül ez a feltételezés igazolásra, feltárásra.

A jelen tanulmány célja, hogy a szakirodalmi feltárást követően a gyakorlatban is vizsgálja a fogyasztói vásárlási döntési folyamatának különböző lépéseit, azonosítsa az érzékelt termékminőség szintjeit, tényezőit és az azok kapcsán észlelt márkákat a magyar fütéstechnikai piacon. A kutatás a 2014-ben megjelent, szakértői megkérdezés eredményeit taglaló kutatás egy következő lépésének tekinthetö, melynek eredményei a fogyasztói megkérdezés eredményeivel az összefoglaló részben kerül összevetésre és kiértékelésre.

\section{A FOGYASZTÓI MEGKÉRDEZÉS EREDMÉNYEI}

Az empirikus kutatáshoz szükösen rendelkezésre álló szakirodalmi forrás alapján, a fogyasztói vásárlási döntési folyamat lépéseinek, illetve a termékminőség szintjeinek és tényezőinek vizsgálatához kétlépcsős (kvalitatív, majd kvantitatív) primer kutatási koncepciót alkalmaztam.

\section{Kutatási koncepció és módszer}

A primer kutatás első lépéseként páros mélyinterjút készítettem ingatlantulajdonos ( 9 ház- és 1 lakástulajdonos) házaspárokkal Nyugat-Magyarországon 2013 őszén. Az interjúk elsődleges célja, hogy feltárja a fogyasztói vásárlói döntéshozatal lépéseit és a minőség érzékelésével kapcsolatos jellegzetességeit (szintek és tényezők). Összességében 10 interjú került lefolytatásra 32-70 év közötti házaspárokkal. A megkérdezettek között 6 pár rendelkezett korábbi vásárlási tapasztalattal, 4 pár pedig elsőként vásárolt fütéstechnikai készüléket. Müszaki megoldás tekintetében hagyományos és kondenzációs kazánt, szilárdtüzelésủ kazánt, cserépkályhát vásároltak a megkérdezettek újépítés vagy fütéskorszerüsítés céljából. A mintavételhez a hólabda módszert alkalmaztam, az interjúk kiértékelése pedig az Nvivo 10 programmal, interjúvázlat és készített jegyzetek segítségével történt. A mélyinterjúk eredményei a második lépcsős, kvantitatív kutatás alapjául szolgáltak.

$\mathrm{Az}$ online kérdőívek 2013 decemberében kerültek kitöltésre a magyar lakosság körében. $\mathrm{Az}$ alapsokaságot az Ipsos Interactive Services online panelja biztosította, a Bosch Thermotechnik $\mathrm{GmbH}$. finanszírozásában. A panel a magyar, 18 éven felüli, internettel rendelkező lakosságot reprezentálja, azonban a reprezentativitás a magyar potenciális fütéstechnikai vásárlói sokaságra nem garantálható. Összességében 417 kérdőív került teljességében kitöltésre. A válaszadók saját ingatlannal rendelkeznek és az elmúlt, ill. elkövetkező 18 hónapban fútéstechnikai terméket vásároltak/ szándékoznak vásárolni.

\section{A páros mélyinterjúk eredményei}

A mélyinterjúk résztvevői minden esetben saját tulajdonnal rendelkező (családi ház, lakás) házaspárok, akik legalább egy alkalommal vásároltak saját maguk részére fütéstechnikai berendezést. A mélyinterjú eredményeit a 1. ábra szemlélteti. 


\section{1. ábra: Minőségi ismérvek és a márkaészlelés a fogyasztói vásárlási döntési folyamat egyes szakaszaiban}

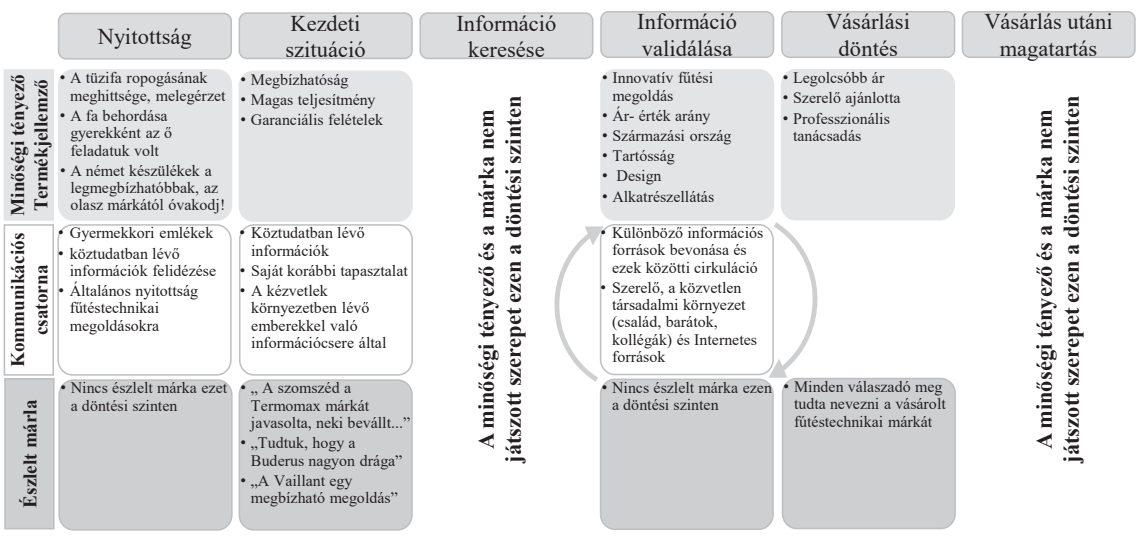

Forrás: saját szerekesztés

A válaszadók az alábbi vásárlási döntési szinteket említették: (a) nyitottság, (b) kezdeti vásárlási szituáció, (c) információ keresése (d) információ validálása (e) vásárlási döntés (f) vásárlás utáni magatartás. A minőség észlelése (a) a nyitottság, (b) a kezdeti vásárlási szituáció, (d) az információ validálás és (e) a vásárlási döntés szintjein történt. A megkérdezettek a minőségi tényezőket termékjellemzők formájában észlelték, melyek a vásárlási döntési folyamat eltérő szakaszaiban különböző szerepet játszottak. A válaszadók továbbá a minőségi tényezők információs forrásával és az észlelt márkákkal kapcsolatban hívtak elő emlékeket.

A megkérdezettek a vásárlási folyamat kezdetén nyitottságukat fejezték ki a fütéstechnikai termékekkel kapcsolatban, mely az egész vásárlási döntési folyamat során jelent volt: fontosnak tartják az új müszaki megoldások ismeretét. Példákat hoztak korábbi (gyermekkori) emlékeikből és/ vagy a köztudatban lévő információkból. Azonban sem konkrét hirdetést, sem márkát nem tudtak megnevezni a vásárlási döntési folyamat ezen szakaszában. A válaszadók a minőségi tényezőkhöz, technológiákhoz (kandalló, fatüzelésủ kazán, stb.) pozitív érzelmeket és élményeket kapcsolnak (a ropogó tűz ereje, a közös családi élmények, a tüzrakás gyermekkori feladat volt, stb.)

Amint a kezdeti vásárlási szituáció fennáll, és a fogyasztó eldönti, hogy új fütéstechnikai terméket vásárol, a minőségi tényezők szerepe az új termékkel szembeni elvárásokban mutatkozik meg.
Ebben a szakaszban a megbízhatóság, a teljesítmény és a garanciális feltételek kerültek említésre. A megkérdezettek saját korábbi tapasztalatukra illetve a társadalmi környezetből érkező ismeretekre, mint információs forrásokra hagyatkoztak, melyek minőségi tényezőkkel kapcsolatos márkainformációt közvetítettek. (a Buderus drága márka, a Vaillant megbízható, stb.)

Az információkeresés szakaszában a házaspárok nagyrészt maguk kezdték meg a keresést (hat pár) az interneten, különböző gyártói weboldalakon és információs portálokon. Ezen a döntési szinten nem tudtak a válaszadók emlékeket felidézni termékjellemzőkkel, illetve márkákkal kapcsolatban. Mind a 10 pár határozottan állította, hogy ezen a szinten nem hoztak vásárlási döntést, hanem a megszerzett információt számos más forrással validálták. Ez az értékelő folyamat kb. 4-6 lépésből állt, melyben a megkérdezettek tapasztalatot cseréltek számos kommunikációs csatorna bevonásával. Ahogy az egyik pár mesélte: "Elsö körben az Interneten nézelődtünk lehetséges megoldások után, hiszen számunkra fontos volt, hogy a szerelővel konkrét elképzelésekről egyeztessünk. A szerelő által javasolt terméknek különbözö blogokon és fórumokon olvastunk utána, baráti körben, valamint a munkahelyen kollégáknál kérdeztünk utána..." A válaszadók a folyamat bonyolultságát, és az információk értékelésének nehézségét hangsúlyozták. Számos termékjellemző (ipari és lakossági termékek minőségi tényezői) került felsorolásra a validálás során, melyben sem prioritás, sem 
hangsúlyi eltérés nem volt érzékelhető, pl. megbízhatóság, tartósság, ár-érték arány, garanciális feltételek, alkatrészellátás és költsége, stb.

A vásárlási döntésben a válaszadók szerint a legolcsóbb ár játszotta a fö szerepet (4 házaspár esetében), 3-an a szerelő tanácsára cselekedtek, 3-an pedig a leginkább magas szintü szaktanácsadás helyszínén vásárolták a terméket. Minden válaszadó házaspár meg tudta nevezni a megvásárolt terméket/ márkát (említés száma): Junkers (3), Termomax (3), Vaillant (2), Eta (1), Etna (1).

\section{Az online kérdőives megkérdezés eredményei}

Mivel a páros mélyinterjú megkérdezettjei a nyitottság szintjén számos információt hívtak elő a köztudatból a fütéstechnikai termékekkel kapcsolatban, így nyitott kérdés formájában erről kérdeztem a válaszadókat. Összesen a 417 megkérdezett, 251 válaszából a 149 db értékelhető választ érkezett. Számos fütéstechnikai technológiával (39\%), márkával (23\%), tüzelőanyaggal $(19 \%)$, a termék származási helyével $(13 \%)$ és költségekkel $(6 \%)$ kapcsolatos ismeret él a köztudatban. Ezekhez a müszaki megoldásokhoz és márkákhoz minőségi ismérveket társítottak a fogyasztók: pl. legjobb megoldás, leghatékonyabb, megbízható, egyszerü és kényelmes, rossz minőségü, nem térül meg, drága, hatékony, modern, stb.

A válaszadók fütéstechnikai termékekre vonatkozó ismeretét a fütéstechnikai termékekkel kapcsolatos reklámok felidézésével vizsgáltam. $74 \%$ egyáltalán nem emlékezett, $14 \%$ az elmúlt 2 hónapból, $12 \%$ az elmúlt 3 hónapból vagy annál régebbről. Azt a 107 (26\%) válaszadót, akik emlékezni tudtak valamilyen fütéstechnikai termékekre vonatkozó hirdetésre, tovább kérdeztem a hirdetésben szereplő műszaki megoldásról.
A megújuló energiákon alapuló fütéstechnikai és energetikai megoldások (napelem, napkollektor, hőszivattyúk $40 \%$ felett) magas említésszámot kaptak, melyekhez leginkább a Bosch márkát társítják a válaszadók (19\%). A Junkers márkát a válaszadók $8 \%$-a (5. hely), a Buderus márkát a válaszadók 6\%-a (6. hely) említette, melyek alacsony említésszámnak felelnek meg. Számos márka kapott hasonlóan alacsony említési számot (3\% vagy alatta), mely szerint több márka él a válaszadók tudatában. A „nem emlékezők” aránya a második helyen szerepel, mely egy magas említési számnak felel meg a reklámra emlékezők körében.

A kezdeti vásárlási szituáció szintjén a megkérdezettek a minőségértékelési tényezőket az új fütéstechnikai termékkel szemben támasztott elvárásként kezelték. A megkérdezettek nagy többsége számos tényezőt tartott fontosnak, többek között a tartósság (95\%), a megbízhatóság (95\%), az ár-érték arány $(92 \%)$, a garancia $(85 \%)$ és a szervizszolgáltatás (72\%) fontosságával értett egyet. Ezen a döntési szinten is a Bosch (23\%) és a Vaillant $(13 \%)$, valamint a tradicionális magyar márka, a Hajdu (12\%) feleltek meg az fogyasztók elvárásainak. A Junkers márkát a válaszadók $9 \%$-a választotta (4. hely), míg a Buderus márka a válaszadók 3\%-a szerint felel meg az elvárásoknak. A megkérdezettek 7\%-a nem tudott ezen a döntési szinten márkát felidézni

Az információ validálása szintjén a válaszadók $85 \%$-a validálta a megszerzett információt, ezen válaszadók közel 50\%-a további 1-3 alkalommal, $30 \%$-a pedig 4-6 alkalommal tette mindezt. A validálás forrásai között szerepel a szerelö, különböző Internetes források (gyártói weboldalak, online információs portálok, blogok és fórumok, stb.), család, barátok és egyéb, a fogyasztó társadalmi környezetéhez tartozó szereplő. A végső márkaválasztás eredményét a 2. összefoglaló ábra szemlélteti. 


\section{2. ábra: A minőségértékelési tényezők és márkák szerepe a vásárlási döntés szakaszában}

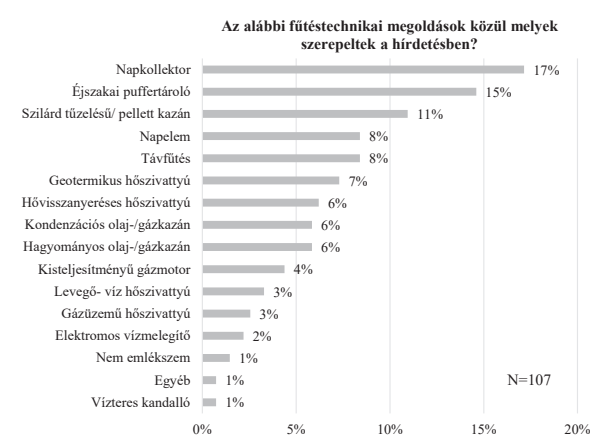

Forrás: saját szerkesztés

A végső döntésnél a válaszadók a Bosch (23\%), majd a Hajdu (14\%) és a Vaillant 13\%) márkák között hezitáltak, a megvásárolt termék márkájára azonban $23 \%$ nem emlékszik. A választást eldöntő tényező a megkérdezettek 39\%-a szerint az árérték arány volt, a megbízhatóságot a válaszadók harmada jelölte meg. A korábbi vásárlási döntési folyamat szintjein fontosnak ítélt tényezők, pl. a készülék tartóssága, az alkatrész-ellátottság és költsége, a garanciális feltételek, stb. a végső döntés és a márkaválasztás szintjén egyáltalán nem, vagy csak elenyésző mértékben játszanak szerepet.

\section{MEGÁLLAPÍTÁSOK}

A 2014-ben közölt szakértői megkérdezésben (Vágási és tsai. 2014) a fogyasztói piac Garvin-féle minőségtényezőit vettük alapul, és ezek fogyasztói megítélését szerviz szakemberek megkérdezésével a Bosch, Buderus és Junkers márkák kapcsán vizsgáltuk. Akkori feltételezésünk, mely szerint a fogyasztók a vásárlási döntés meghozatala során az ár-minőség viszonyát tartják a legfontosabb értékelő ismérvnek, a szakértők véleménye szerint nem igazolódott be. A szakértők szerint a fogyasztók a szervízszolgáltatást, a megbízhatóságot valamint a termék garanciális idejét tartják a legfontosabb döntési ismérvnek. A fogyasztói megkérdezés eredményei azonban igazolják korábbi feltételezést, mely szerint a fogyasztók legnagyobb része (39\%-a) ténylegesen az ár-érték arányt tartja a márkaválasztás döntő ismérvének.

Továbbá a 2014-ben megjelent kutatásban feltételeztük, hogy a magyar piac három vezető márkája(Bosch, Buderus, Junkers) egy-egyminőségi

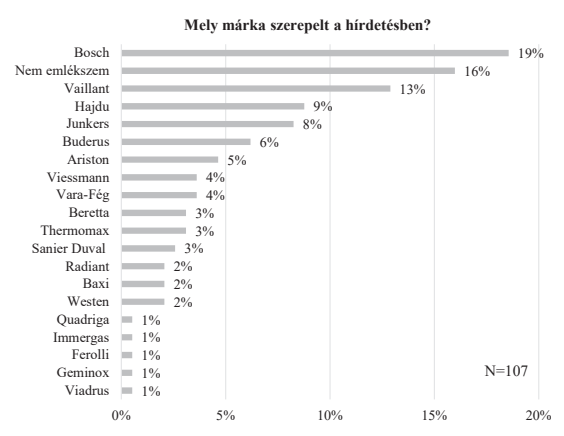

ismérvhez rendelhetőek: a Buderus márkánál a megbízhatóság, a Bosch márkánál a szervízszolgáltatás, a Junkers márkánál az ár-minőség tényezője dominál. A szakértői megkérdezés eredménye szerint mind a három márka esetében a szervízszolgáltatás kapta a legmagasabb említési számot, így az akkori feltételezek nem igazolódtak be. Megemlítendő, hogy a szervizes szakemberek egyszerre több márkát is képviselnek Magyarországon

A fogyasztói megkérdezés eredményei szerint a fogyasztók a vásárlási döntési folyamat különböző szintjén érzékelik a minőséget és a márkákat, azonban fütéstechnikai reklámra a fogyasztók csak kis csoportja emlékezett. A kezdeti vásárlási szituáció a tartósság, a megbízhatóság, az ár-érték arány, a műszaki paraméterek, a garanciával és a könnyü használat mentén észlelték a válaszadók a minőséget. A validálás és a végső döntés szintjén pedig az ár-érték arány és a megbízhatóság játszotta a döntő szerepet. A korábban fontosnak tartott tartósság, az alkatrész-ellátottság, a garanciális feltételek illetve a könnyü használat egyáltalán nem került választásra vagy csak elhanyagolható súllyal (pár \%-ban).

A márkaészlelés tekintetében a 3. összefoglaló ábra 2014-ben megjelent kutatáshoz hasonlóan a Junkers, Buderus és Bosch márkákat teljesítményét szemlélteti, legjelentősebb piaci versenytársuk, a Vaillant és Viessmann mellett. A \%-os értékek az egyes márkák említési gyakoriságát jelölik, a számok pedig a márkák említési rangsorát mutatják. 


\section{3. ábra. Márkaészlelés a vásárlási döntési folyamat mentén}

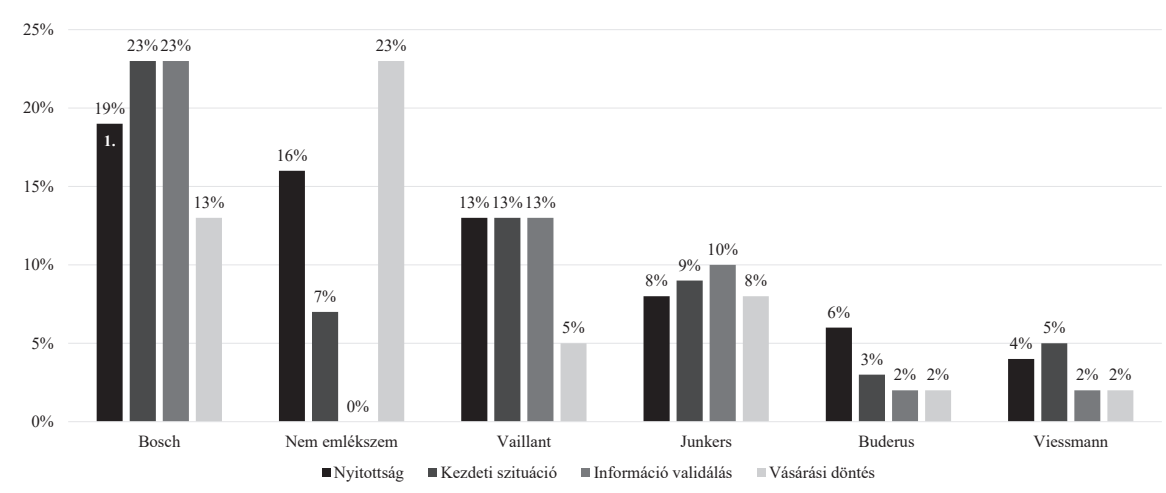

Forrás: saját szerkesztés

A vásárlási döntési folyamat során számos (magyar és nemzetközi) márka kapott közel hasonló (alacsony) említési gyakoriságot, mely a magyar fütéstechnikai piac heterogenitására utal. Továbbá úgy vélem, hogy az eredmények tekintetében a márkák nehezen diverzifikálhatók, így az a termék kerül megvásárlásra, mely az ár-érték arány, mint minőségtényező tekintetében a legjobban teljesít.

A Bosch márka megtartotta a vezető helyét a vásárlási döntési folyamat során, a legmagasabb említésszám mellett is csak a válaszadók 23\%-a említette. A márkák a végső döntés szakaszában szóródtak a leginkább, itt a Bosch márka 13\%-al végzett a második helyet, mivel a fogyasztók legnagyobb aránya nem emlékezett a vásárolt termék márkájára. A Junkers márka a vásárlási döntési folyamat mentén végig megtartotta 4. helyét, a Boschnál jóval alacsonyabb említési számmal. Mindkét márka legjelentősebb piaci versenytársa, a Vaillant márka 13\%-al a vásárlási döntési folyamat mentén a 2 . illetve a 3 . helyen szerepelt, a végső döntés szakaszában jelentősen pozíciót vesztett. Ennek oka lehet, hogy az ár-érték arány, illetve a megbízhatóság tekintetében rosszul szerepel. A Buderus márkát viszonylag többen említették a nyitottság szakaszában, azonban a teljes vásárlási döntési szakasz során alacsony rangsorolást kapott. Véleményem szerint a Buderus márka magas árfekvése okán (magas minőségének észlelése ellenére) kerül elutasításra. A Viessmann márka a Buderushoz hasonlóan összességében alacsony említésszámot kapott, mely a hasonlóan magas árfekvéssel magyarázható.

\section{ÖSSZEGZŐ KÖVETKEZTETÉSEK ÉS JAVASLATTÉTEL}

Az empirikus feltáró kutatásom megkérdezettjei komplex és bonyolult vásárlási folyamatként érzékelték a fütéstechnikai termékek vásárlását. Bár a fogyasztók általános nyitottságot mutattak számos fütéstechnikai megoldás, technológia, márka és minőségi tényező iránt, a végső döntésnél a korábban vélt tényezők fontossága érvényét vesztette. Feltételezhető, hogy a magyar fütéstechnikai piac nagyban heterogén, sok márka több terméke verseng a fogyasztók döntéséért, melyben az árérték arány és a megbízhatóság játssza a legfontosabb szerepet. Amennyiben valamely márka nem tudja tartani versenyelönyét e két legfontosabb tényező tekintetében, úgy a fogyasztók részéről elutasításra kerül.

Ahogy 2014-es szakértői megkérdezés és jelen tanulmány eredményeinek ütköztetése során megállapítottam, hogy a fogyasztók más minőségértékelési tényezőket tartanak fontosnak a végső döntés alkalmával, mint ahogy a szakemberek a fogyasztókról gondolnák. Ez alapvető kérdést vet fel a gyártók értékesítési-és marketingstratégiájában. A vállalatok rendszerint a szerelő és szervizes szakembereket tekintik elsődleges célcsoportjuknak és hagyatkoznak arra, hogy a gyártó termékét népszerüsítsék és ajánlják tovább a fogyasztók felé. Azonban a magyar fütéstechnikai piacon egy szerelö egyszerre több fütéstechnikai márkát is képvisel a fogyasztók felé, így amennyiben a szerelő rosszul méri fel a fogyasztói igényeket, úgy a márkák és technológiák ajánlásának hitelessége mind a fogyasztók, mind pedig a gyártók 
szemszögéből kérdésessé válik. Feltételezhető, hogy ennek okán bizalmatlanság alakulhat ki a fogyasztókban, hogy vajon a szerelő szakember ténylegesen a fogyasztói igényeknek (minőségi tényezőknek) megfelelő márkát javasolja, az amúgy is komplexnek és bonyolultnak itélt vásárlási döntési folyamat során. Ezzel magyarázható a validálási szakasz hozza, illetve az internetes források jelentősége a vásárlási döntési folyamatban.

A fütéstechnikai termékeket gyártó vállalatok részére javaslom, hogy aktív márkaépítés és márkaismertség helyett, a fogyasztó számára fontosnak vélt minőségi ismérvek mentén határozza meg marketingkommunikációs eszközrendszerét és koncentrálja költségvetését. Javasolom, hogy talán az eddig hatékonynak vélt szerelői illetve hagyományos kommunikációs csatornákat (pl. újsághirdetés, rádiós és tévés kampányok, kiállításokon való megjelenés, stb.) váltsák fel a fogyasztó számára hitelesnek tartott közvetítői csatornák, melynek pontosabb meghatározásához és azonosításához további feltáró kutatás szükségességét látom a megfelelö fogyasztói kör megkérdezésének segítségével.

\section{HIVATKOZÁSOK}

Achtnicht, M. (2011), "Do environment benefits matter? Evidence from a choice experiment among house owners in Germany", Ecological Economics, 70 11, 2191-200 DOI: https://doi. org/10.1016/j.ecolecon.2011.06.026

Aune, M. (2007), „Energy comes home”, Energy Policy, 35 5457-65 DOI: https://doi. org/10.1016/j.enpol.2007.05.007

Chen, C., Zheng, Y., Mu L. (2012), „Assessment for central heating systems with different heat sources: A case study," Energy and Buildings, 48 168-74 DOI: https://doi.org/10.1016/j. enbuild.2012.01.025

Claudy, M. C., Michelsen, C., O’Driscoll, A. (2011), "The diffusion of microgeneration technologies - assessing the influence of perceived product characteristics on home owners' willingness to pay", Energy Policy, 39 1459-69 DOI: https:// doi.org/10.1016/j.enpol.2010.12.018

Cowan, H. J. (1987), "A Note on the Roman Hypocaust, the Korean On-dol and the Chinese Kang”, Architectural Science Review, 30 4, 123-7 DOI: https://doi.org/10.1080/00038628. 1987.9696614

Day, A. R., Ratcliffe, M. S., Shepherd, K. J. (2003), Heating Systems, Plant and Control, Oxford: Blackwell DOI: https://doi. org/10.1002/9780470774458

Faiers, A., Neame, C., Cook, M. (2007), „Towards a contemporary approach for understanding consumer behaviour in the context of domestic energy use", Energy Policy, 35 4381-90 DOI: https://doi.org/10.1016/j.enpol.2007.01.003

Garvin, D. A. (1988), Managing Quality: The Strategic and Competitive Edge, New York: The Free Press

Gustavsson, L., Joelsson, A., (2007), "Energy conservation and conversion of electrical heating systems in detached houses", Energy and Building, 39 717-26 DOI: https://doi.org/10.1016/j. enbuild.2006.06.014

Hansen, D. L. (1999), Indoor Air Quality Issues, New York: Taylor \& Francis

Hart, S. J. (1989), „Product Deletion and the Effects of Strategy", European Journal of Marketing, 23 10, 6 - 17. DOI: https://doi.org/10.1108/ eum0000000000591

Kaezing J., Wüstenhagen, R., (2008), “Understanding the Green Energy Consumer", Marketing Review St. Gallen, 25 4, 12-6 DOI: https://doi. org/10.1007/s11621-008-0057-3 
Mahapatra, K., Gustavsson, L. (2008a), “An adopter-centric approach to analyze the diffusion patterns of innovative residential heating systems in Sweden", Energy Policy, 36 577-90 DOI: https://doi.org/10.1016/j.enpol.2007.10.006

Mahapatra, K., Gustavsson, L. (2008b), "Innovative approaches to domestic heating: homeowners' perception and factors influencing their choice of heating systems", International Journal of Consumer Studies, 32 75-87 DOI: https:// doi.org/10.1111/j.1470-6431.2007.00638.x

Mahapatra K., Gustavsson L. (2010), “Adoption of innovative heating systems - needs and attitudes of Swedish homeowners", Energy Efficiency, 3 1-18 DOI: https://doi.org/10.1007/ s12053-009-9057-7

Michelsen, C. C., Madlener, R., (2013), „Motivational factors influencing the homeowners' decisions between residential heating systems: An empirical analysis for Germany", Energy Policy, 57 221-33 DOI: https://doi.org/10.1016/j. enpol.2013.01.045

Munkácsi, N., Grőger, N. (2011), „A termékminőség szerepe a müszaki fogyasztási termékek vásárlási döntésében: Marketing aspektusok és kutatási kérdések." BME Tudományos Diákköri Konferencia, Budapest

Nair, G., Mahapatra, K., (2011), "Policy instruments to promote building energy efficiency from an end user point of view", ECEEE Summer Study Proceedings

Rai V., Cale Reeves D., Margolis R., (2016), “Overcoming barriers and uncertainties in the adoption of residential solar PV", Renewable Energy, 89 498-505 DOI: https://doi.org/10.1016/j. renene.2015.11.080

Rogers, E. M. (2003). Diffusion of Innovation, 5/e. Free Press, New York

Rouvinen, S., Matero, J. (2013), "Stated preferences of Finnish private homeowners for residential heating systems: A discrete choice experiment", Biomass and Bioenergy, 57, 22-32 DOI: https:// doi.org/10.1016/j.biombioe.2012.10.010

Stolyanova, E., Le Cadre, H., Osso, D., Allibe, B. (2015), "Stated Preferences for Space Heating
Investments", Economic Modelling Conference, 15-17 July 2015, Boston, United States

Strupeit, L., Palm, A., (2016), "Overcoming the barriers to renewable energy diffusion: business models for customer-sited solar photovoltaics in Japan, Germany and the United States", Journal of Cleaner Production, 123 124-36 DOI: https:// doi.org/10.1016/j.jclepro.2015.06.120

Tapaninen, A., Seppänen, M., Mäkinen, S. (2009a), "Characteristics of innovation: a customer-centric view of barriers to the adoption of a renewable energy systems", International Journal of Agile Systems and Management, 4 1/2, 98-113 DOI: https://doi.org/10.1504/ ijasm.2009.023250

Tapaninen, A., Seppänen, M., Mäkinen, S. (2009b), "Characteristics of innovation in adopting a renewable residential energy system", Journal of Systems and Information Technology, 11 4, 347-66 DOI: https:/doi. org/10.1108/13287260911002495

Vágási M. (1998), A marketing-menedzsment alapjai, Budapest: Múegyetemi Kiadó

Vágási M. (2001), Újtermék- marketing, Budapest: Nemzeti Tankönyvkiadó

Vágási M., Munkácsi N., Grőger N. (2014), „Adalékok a marketing termékklasszifikációjához: Müszaki fogyasztási termékek esete", Marketing \& Menedzsment, 48 1, 59-70

Wissner, M., (2014), "Regulation of district-heating systems", Utilities Policy, 31 63-73 DOI: https://doi.org/10.1016/j.jup.2014.09.001

Wüstenhagen R., Kaezing, J. (2010), „The Effect of Life Cycle Cost Information on Consumer Investment Decisions Regarding Eco-Innovation", Journal of Industrial Ecology, 14 1, 121-36 DOI: https://doi.org/10.1111/j.15309290.2009.00195.x 
Munkácsi Noémi, PhD hallgató

noemi.munkacsi@gmail.com

Budapesti Műszaki és Gazdaságtudományi Egyetem

Gazdaság-és Társadalomtudományi Kar

Gazdálkodás- és Szervezéstudományi Doktori Iskola

\section{Special marketing characteristics of heating products \\ Perceived quality attributes of residential heating products along the decision-making process}

\section{THE AIMS OF THE PAPER}

End customers make their investment-like purchase decisions with heating products for 15-20 years' time. The goal of the paper is to reveal the special marketing characteristics of the decision-making process by identifying the perceived quality attributes and brands at the diverse stages of the purchase process. Furthermore, the goal of the paper is to validate the results of a former research conducted with installers and service technicians about end customers' quality and brand perceptions.

\section{METHODOLOGY}

A 2-step empirical research (1. Focus group interviews, 2. Quantitative online questionnaire) was conducted with end customers in Hungary in December 2013.

\section{MOST IMPORTANT RESULTS}

End customers perceive quality attributes at the diverse stages of the purchase process analog to both industrial and residential market characteristics. End customers find price-performance ratio the deciding quality attribute by the final decision, which supports the assumption of the previous research and contradicts the opinion of service technicians about the end customers' preference.

\section{RECOMMENDATIONS}

Based on the research results, manufacturers of heating products should optimize their sales- and marketing strategy towards both installers and end customers.

Keywords: residential heat market, end customer purchase decisions, perceived quality attributes 